\title{
スマートフォン利用者の個人情報保護 安全・安心な利用環境確保に向けた取り組み
}

The requirements for the data protection of smartphone users

Ensuring a safe and secure usage environment

新保 史生 ${ }^{1}$

\section{SHIMPO Fumio ${ }^{1}$}

1 慶應義塾大学総合政策学部（２２52-8520 神奈川県藤沢市遠藤5322） E-mail : shimpo@sfc.keio.ac.jp

1 Department of Policy Management, Keio University (5322 Endo Fujisawa-shi, Kanagawa 252-8520)

原稿受理 $(2012-10-10)$

情報管理５5(9), 629-637, doi: 10.1241/johokanri.55.629 (http://dx.doi.org/10.1241/johokanri.55.629)

著者抄録

スマートフォンの利用者数が急激に増加する一方で，利用者が不安を覚える問題の発生も増加している。スマートフォ ンを介してどのような情報が取得され利用されているのか，利用者が認識することができないまま，不透明な情報の 取扱環境が存在する。不正アプリによる，スマートフォン内部に記録されているさまざまな個人情報の不正取得およ び外部送信が問題となる事件が発生している。そこで，本稿では，現行の個人情報保護法に照らして，スマートフォ ンを介して取得し利用される個人情報の取扱いにあたって，具体的にどのような対応が求められるのか整理をした上 で，スマートフォンを安全・安心に利用するにあたつての指針として，セキュリティとプライバシー・個人情報保護 の両面からの取り組みを紹介する。

キーワード

個人情報，プライバシー，個人情報保護，スマートフォン，セキュリティ

\section{1. スマートフォンの普及と現状}

スマートフォンの利用者数の急速な増加1）は目覚 ましいものがあり，その増加率は昨年1年間で倍増と の調査結果注1)もある。スマートフォンのメリットは， フィーチャーフォンとは異なり，パソコンの利用環 境に近い情報処理能力を有し，利用者が自らが利用 する機能やアプリケーションを都合に合わせて取捨 選択することができる点にある。なお，「フィーチャー フォン」とは，スマートフォンに該当しない既存の
多機能携帯電話で「ガラパゴス携帯」とも呼ばれる 既存の携帯電話端末のことである。野村総合研究所 の北俊一上級コンサルタントが，日本国内における 携帯電話の動向をガラパゴスという用語を用いて表 現したことが，現在の国内における携帯電話市場の 状況を的確に表した表現として広く用いられるよう になつたものである。

しかし，以前は小型の携帯端末と言えば，ウォー クマンをはじめとして日本製の装置が世界を席巻し ていたが，スマートフォンについては日本製品は後 
塵を扯している感は否めない。スマートフォンのOS も，アップル (iOS)，グーグル (Android)，マイ クロソフト (Windows Phone+Windows Mobile)， Research In Motion（BlackBerry）のいずれかの事業 者が提供するプラットフォームを利用せざるを得な い状況にある。

\section{2. 基本的な心得}

スマートフォンをめぐる問題は，契約や通信料金 （とりわけパケット代）をめぐる問題，機器の操作や 利用環境をめぐる問題など，それを利用するにあたつ ての問題，ならびに，個人の権利利益侵害やセキュ リティの問題など，その利用に伴う問題に分けられ る。つまり，スマートフォンの利用をめぐる問題（ト ラブル）は，新たな法律問題にとどまらず従来から の通信サービスの利用と同様の問題も多い。

したがって，法的課題を論ずる以前の問題として， そもそもスマートフォンを利用するにあたって利用 者が最低限注意すべきことがある。

例えば，スマートフォンは，「携帯端末」ではある が「携帯電話」とは異なる特性を有するという認識 を持つ必要がある。スマートフォンは携帯電話と同 様に通信や通話をする装置ではあるものの，携帯電 話よりはむしろパソコンに近い。通信路（通信の方 法）についても，携帯電話事業者が提供するネット ワークにとどまらず，回線設置事業者や個別の基地 局を介した無線LANによる通信も可能である。よっ て，電話を掛けることが主な利用目的であるならば， スマートフォンは必ずしも必要がない場合もある。 しかし，携帯電話事業者も，スマートフォンを積極 的に売り込む営業戦略を展開しており，本来，スマ一 トフォンが必要のない人たちにまでその利用が拡大 していることも，新たな問題を発生させる原因にも なっている。

表示される注意事項を読んでいない，何でも同意 またはOKのボタンを押してしまうなど，本来守るべ
き基本的かつ最低限必要な事柄が行われていないこ とによって生ずる問題も多い。

単に，利用者がスマートフォンの特性や問題を「理 解していない」「理解することができない」ことに よる問題だけでなく，利用者には「理解できないよ うになっている」ことや「理解しづらい」ことに起 因する問題もある。

\section{3. 不透明な情報の取扱環境の存在}

ネットワークに関するさまざまなサービスにおい ては，実際にどのように情報が取り扱われ，どのよ うに機能が動作しているのか，目に見えない部分も 多いことから，違法・不正な情報処理がなされてい ても利用者が認識できないことも多い。

パケット通信のパケット量は，通信を行っている 際には感覚的にどの程度の通信量があるのか把握す ることが困難であり，また，スマートフォンは自動 的に通信を行っているため，予想以上にパケットを 消費していることがある。携帯電話会社の交換機が 大量の通信量によってダウンし，携帯電話の利用に 支障が生じた事例が発生したことは記憶に新しい。 大量のパケットを消費する通信を制限すれば問題は 解決するが，そのような通信を制御したりサービス を制限することは，自由なインターネット環境の確 保に反するものとして規制される方向にある。これ を「「ネットワーク中立性」2) という。

さらに，スマートフォンの長所は，さまざまなア プリケーションの大変便利な機能を自分の好みに合 わせて利用することができる点が醍醐味である。と ころが，便利な機能に乗じて，不正なアプリによつ て不正な情報の取得が横行していることは後述の通 りである。利用者にとつては，どのような情報が取 り扱われているのか，実際に把握することが困難で あり，具体的に，どのようなセキュリティ対策を実 施しなければならないのか，未だ十分に理解されて いない側面が多いのは事実であろう。 


\section{4. 不正アプリの問題}

スマートフォンの利用者が不安を覚える問題の1つ として，不正アプリの問題がある。最近の動向 ${ }^{3)}$ は， スマートフォン内部に記録されているさまざまな個 人情報の不正取得および外部送信，広告の強制表示， 有料SMSの強制送信等であり，また不正に金銭を要 求する「ワンクリック詐欺」型のアプリも出現して いるとされる。

大きく報道がなされた事例を列挙すると，「カレロ グ」（恋愛支援アプリと称し，位置情報，バッテリー 残量，アプリ一覧，通話記録の閲覧が可能)，「アッ プティービー」(端末固有番号，アプリ一覧，アプ リ起動歴などの情報を無断で収集し送信)，金魚す くいゲーム（位置情報を米国の広告会社に送信す るアプリ。150万人が利用)，「ビューン」（電子書 籍閲覧ソフトが，利用者が読んだ雑誌などの内容 やページごとの閲覧時間を記録し送信)，iPhone 用 のアプリケーション「マガストア」（閲覧履歴を送 信)，「ANDROIDOS_FAKETIMER（フェイクタイマー)」 (画面に金銭請求を促すポップアップを表示)，「the Movie」（スマートフォン利用者の個人情報などを外 部送信)，電池の寿命を延ばすと銘打って情報を窃 取する，いわゆる「電池長持ち」アプリ (「Android. Ecobatry $\lrcorner\lceil$ Android.Sumzand $\lrcorner\lceil$ Android.Ackposts」「わ んこアプリ発見〜w」）なども登場している。

これら不正アプリの中には，スマートフォン内部 に記録されている個人情報を不正に取得するものも あるが，当該行為は「不正」ではなく「違法」行為 として処罰の対象にもなり得る。平成23年7月14日に 施行された「情報処理の高度化等に対処するための 刑法等の一部を改正する法律」(平成23年6月24日公 布）において，不正指令電磁的記録に関する罪（い わゆる「ウイルス作成罪」）が定められた。不正アプ リの動作が，正当な理由がないのに，人の電子計算 機における実行の用に供する目的で，人が電子計算 機を使用するに際してその意図に沿うべき動作をさ
せず，またはその意図に反する動作をさせるべき不 正な指令を与える電磁的記録等を作成または提供し た場合等に該当する場合には，不正アプリの供用が ウイルス作成罪にあたる場合もあるといえよう。

\section{5. 個人情報の適正な取扱い}

スマートフォンを介して取り扱われる情報が「個 人情報」に該当する場合であって，かつ，その情報 を取り扱う者が，「個人情報取扱事業者」に該当する 場合は，「個人情報の保護に関する法律」（個人情報 保護法）（平成15年法律第57号）が定める義務が適用 される。

個人情報保護法の基本理念は，「個人情報は，個人 の人格尊重の理念の下に慎重に取り扱われるべきも のであることにかんがみ，その適正な取扱いが図ら れなければならない。(第3条)」と謳つており，個人 情報保護法の義務規定が適用されない者であっても， 個人情報の適正な取扱いを行わなければならない己 とはいうまでもない。

また，個人情報取扱事業者が電気通信事業法の定 める電気通信事業者にあたる場合は，「電気通信事業 における個人情報保護に関するガイドライン（平成 16年総務省告示第695号)」屯遵守する必要がある。

その他，総務省「利用者視点を踏まえたICT サービスに係る諸問題に関する研究会」の第二 次提言 (http://www.soumu.go.jp/menu_news/ s-news/02kiban08_02000041.html) が2010年（平成 22年）5月に発表され，「ライフログ活用サービスに 関する配慮原則」が示されていることから，いわゆ るビッグデータの活用や行動ターゲティング広告等 において個人情報等を利用する場合には，当該配慮 原則に留意した上での取扱いが求められる。

以上を踏まえ，現行の個人情報保護法に照らして， スマートフォンを介して取得し利用される個人情報 の取扱いにあたつて，具体的にどのような対応が求 められるのか私論を表1に示しておきたい。 
表1 スマートフォンを介して取り扱われる個人情報の適正な取 扱いにおいて必要なこと

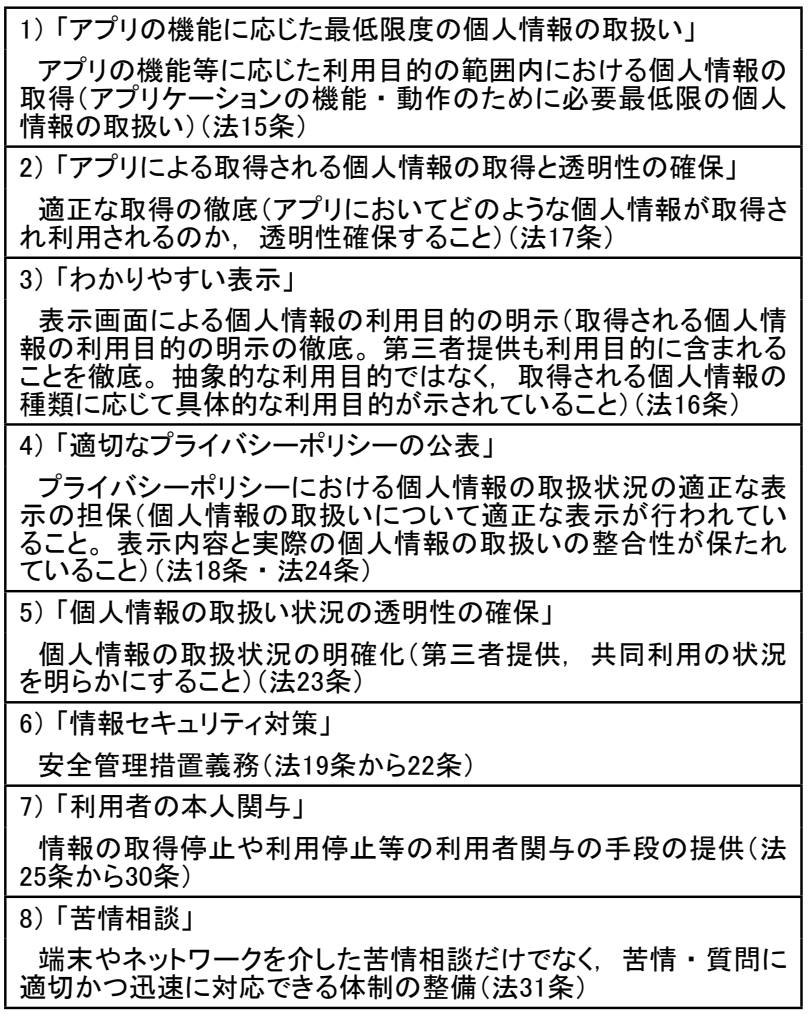

\section{6. スマートフォンとセキュリティ}

スマートフォンを安全・安心に利用するにあたつ ては，利用者情報が適切に取り扱われ，かつ，セキュ リティが確保された上で利用することが前提となる。

スマートフォンの普及に伴い，職場においても 従業員が利用する携帯端末を業務において積極的 に利用することを目指す，BYOD（Bring Your Own Device，業務における私物利用）が提唱されている。 そもそも，情報セキュリティを確保する上で携帯端 末の管理は情報漏洩の危険性が高いことから，従来 からその利用にあたつては管理の難しさが指摘され てきた。その点を踏まえて，情報セキュリティを確 保し適切に利用するための方策を慎重に検討した上 で，業務における私物スマートフォンを利用するこ とが求められる。

セキュリティに関する具体的な対応策は，総務省 「スマートフォン・クラウドセキュリティ研究会」の
表2 スマートフォン情報セキュリティ3か条(利用者が最低限 取るべき情報セキュリティ対策)

1. OS(基本ソフト)を更新

スマートフォンは, OSの更新(アップデート)が必要です。古い OSを使っていると, ウイルス感染の危険性が高くなります。更新 の通知が来たら，インストールしましょう。

2. ウイルス対策ソフトの利用を確認

ウイルスの混入したアプリケーションが発見されています。スマー トフォンでは，携帯電話会社などによつてモデルに応じたウイルス 対策ソフトが提供されています。ウイルス対策ソフトの利用につい ては, 携帯電話会社などに確認しましよう。

3. アプリケーションの入手に注意

アプリケーションの事前審査を十分に行っていないアプリケー ション提供サイト(アプリケーションの入手元)では, ウイルスの混 入したアプリケーションが発見される例があります。OS提供事業 者や携帯電話会社などが安全性の審査を行っているアプリケー ション提供サイトを利用するようにしましよう。インストールの際に はアプリケーションの機能や利用条件に注意しましょう。

最終報告として，「スマートフォンを安心して利用す るために実施されるべき方策」(http://www.soumu. go.jp/menu_news/s-news/01ryutsu03_02000020. html）（平成24年6月29日）が公表されている。

研究会では，スマートフォンの情報セキュリティ レベルの向上，特にマルウェアや外部からの攻撃に 対処するために早急に講ずべき対策として，携帯電 話事業者および端末製造事業者が導入を検討すべき 情報セキュリティ対策，ならびに利用者への普及啓 発の内容や周知の方法について，有効かつ現実に即 した方策を，昨年12月に中間報告としてとりまとめ が行われている。その後，利用者から実際の被害に 関する相談・報告が寄せられるなど，脅威が現実の ものとなってきたこともあり，スマートフォンから のクラウド利用に付随する課題やその対策，スマ一 トフォンを安全に利用するためにクラウドを活用す る方策を含めて，最終報告としてとりまとめがなさ れている。

最終報告では，「スマートフォンを安心して利用す るために実施されるべき方策」が公表されるととも に，スマートフォンの特性に応じたセキュリティ対 策のあり方について検討がなされ，盗難・紛失対策 や他人による不正利用防止対策など，従来の携帯電 話と同様の対策が必要であることから，利用者が最 低限実施すべき情報セキュリティ対策について，「ス マートフォン情報セキュリティ3か条」（表2）が公 
表されている。

「スマートフォンを安心して利用するために実施さ れるべき方策」では，スマートフォンを取り巻く状 況について，昨今のスマートフォンの急激な普及に 伴いさまざまな問題が生じていることをはじめとし て，スマートフォンの特性に起因する問題を確認し， 携帯電話とは異なるスマートフォンの利用に関する 利便性や利用者の意識について現状分析を行ってい る。スマートフォンの利用は，ここ数年普及が始まっ たものである。具体的にどのようなセキュリティ上 の問題があるのか，本報告書以前には具体的な検討 が行われたことはなかったことから，そもそも，ス マートフォンの利用に伴いいかなる問題が生ずるの か確認をすることは重要といえる。

スマートフォンに関わる新たな問題に対応するた めには，個人（利用者），事業者および政府による対 応が必要となる。しかし，利用者自身が講ずること ができる情報セキュリティ対策は限られており，す べての対策を実施することは困難である。そのため， 利用者には「スマートフォン情報セキュリティ3か条」 に基づく取り組みを促すものの，スマートフォンに おける情報セキュリティを確保するための取り組み は，第一義的には事業者による取り組みが実施され， その推進と枠組みの策定および課題の検討に関し政 府が果たすべき役割が明確になっていることが必要 といえる。

さらに，スマートフォンはネットワークに関する さまざまなサービスを利用できるだけでなく，ネッ トワークを介してクラウド・サービス注2)など新たな サービスを利用することができる点も大きなメリッ トである。しかし，そのような大きなメリットには 何らかの脅威や課題が存在することも多い。実際に どのような課題が存在するのか，クラウドを利用す ることに伴う脅威はどのようなものがあるのか，詳 細な分析がなされたことは，スマートフォンを利用 した今後のクラウド・サービスの活用を促進する上 でも大きな意義があるといえる。

\section{7. スマートフォンとプライバシー・個人 情報の保護}

スマートフォンは，個人情報の取扱いに関して大 量の情報の取得ツールであるだけでなく，日常的に 携帯するため個人のプライバシーにも直結する情報 が取得されている。

利用者情報は，パソコンを通じて取得される情報 とは異なり，携帯端末は本人が「携帯」して利用す ることを前提としているため，利用者の通信履歴に とどまらず行動履歴や位置情報等の詳細な情報がリ アルタイムで取得される。スマートフォンで取得で きる情報がそのように多岐にわたることや，その利 用および発展の可能性が携帯電話とは比較にならな いほど高く自由であることから，スマートフォンの 利用者およびサービスを提供する事業者や関係者が， より積極的な情報（個人情報および非個人情報）の 取扱いを目指すのは当然のことといえる。

しかし，スマートフォンにおけるそれらの情報の 取扱いは，実際にどのような情報が取得され利用さ れているのか，情報の取扱状況が可視化されている わけではない。そのため，ブラックボックス内にお ける情報の取扱いに乗じて，利用者が知らないうち にさまざまな情報が取得され利用されかねない状況 が存在している。

利用者側にも自覚を促し，利用するにあたつて最 低限注意すべき事項は前述の通りであるが，不正ア プリを介した不正な情報取得などに利用者個人が対 抗できるはずがない。事業者側にとっても，不透明 な情報の取扱いが行われることが，結果的に安全・ 安心なスマートフォンの利用環境を阻害することと なり，スマートフォンの発展そのものに悪影響を及 ぼしかねないことが懸念されている。そのような状 況を踏まえて，総務省に「スマートフォンを経由し た利用者情報の取扱いに関するWG」が設置され， 2012年1月から検討が開始された。

研究会の成果は，「スマートフォン プライバ 
シー イニシアティブ 一利用者情報の適正な取 扱いとリテラシー向上による新時代イノベーショ ンー」(http://www.soumu.go.jp/menu_news/ s-news/01kiban08_02000087.html）として，2012年 8月7日に公表されている。

この報告書は，スマートフォンを経由した利用者 情報の取扱いに関する現状，取り組み，課題認識と 具体的対応が取りまとめられており，利用者自身が どのような点に注意すべきなのかを示した「スマー トフォン・プライバシー・ガイド」(表3)，事業者に 対しては具体的な指針として「スマートフォン利用 者情報取扱指針」（図1）が公表されている。

「スマートフォン・プライバシー・イニシアティブ」

表3スマートフォン・プライバシー・ガイド

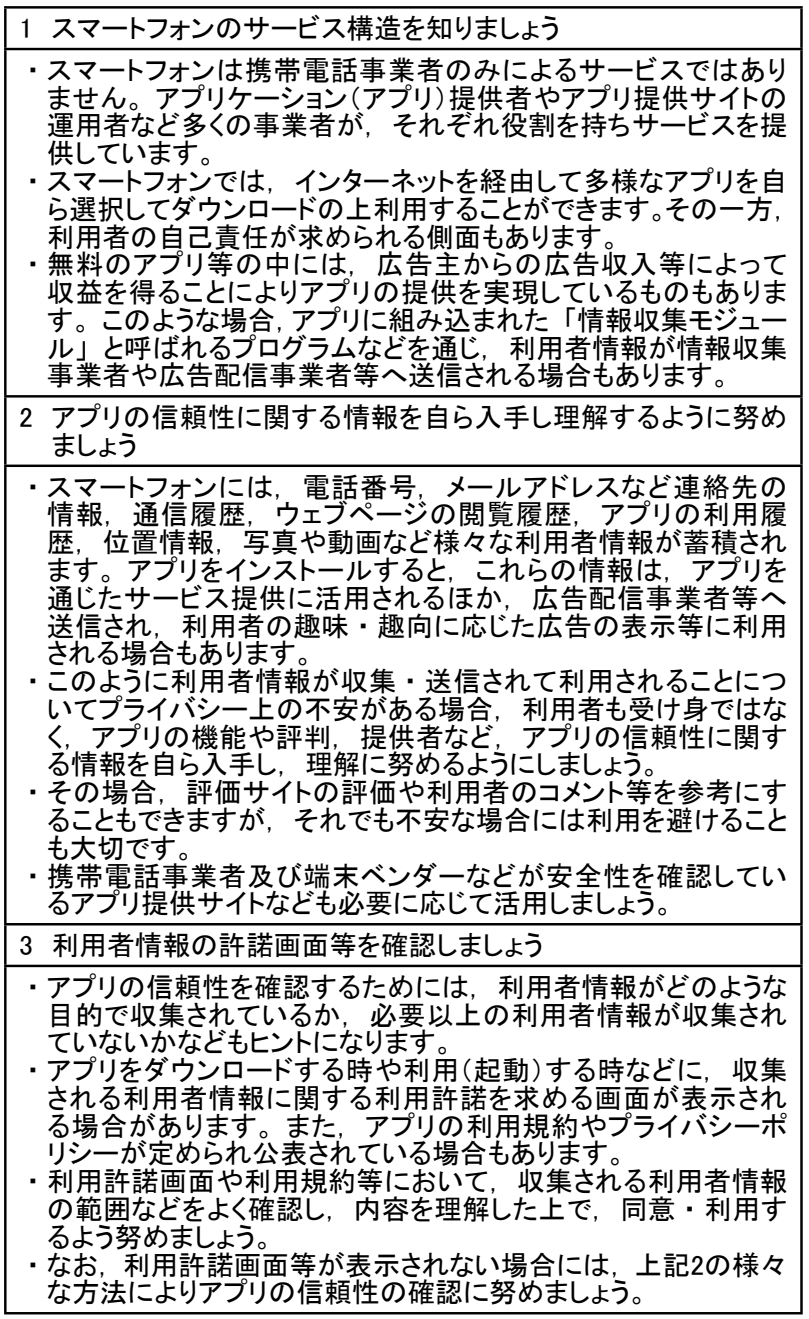

では，スマートフォンの現状とそれに伴う問題につ いては，前述の情報セキュリティに関する報告書同 様に，スマートフォンの急激な普及ならびに従来の 携帯電話とは異なるさまざまな特性を踏まえた上で の検討が行われている。

情報セキュリティ対策と個人情報保護対策が異な る点として，情報セキュリティは保護の対象となる 情報の機密性，完全性，可用性を確保することがそ の目的である。一方，個人情報保護をめぐる問題に おいては，情報セキュリティの確保は，情報の適切 な安全管理措置を実施する対策という観点からは情 報セキュリティ対策と同様ではあるが，情報の取扱 いをめぐるさまざまな課題への対応，とりわけ，情 報を取得してから利用・管理・保存・廃棄する一連 の流れ（ライフサイクル）に沿って，情報の適正な 取扱いに求められる対応を検討することが，その取 り組みの内容といえる。つまり，情報セキュリティ 対策を実施さえすれば個人情報保護への対応も完了 するという考えは誤りである。情報セキュリティ対 策は個人情報保護のための対応の1つの要素に過ぎな い。

以上の点を踏まえて，「スマートフォン・プライバ シー・イニシアティブ」では，スマートフォンを介

スマートフォン利用者情報取扱指針の構造

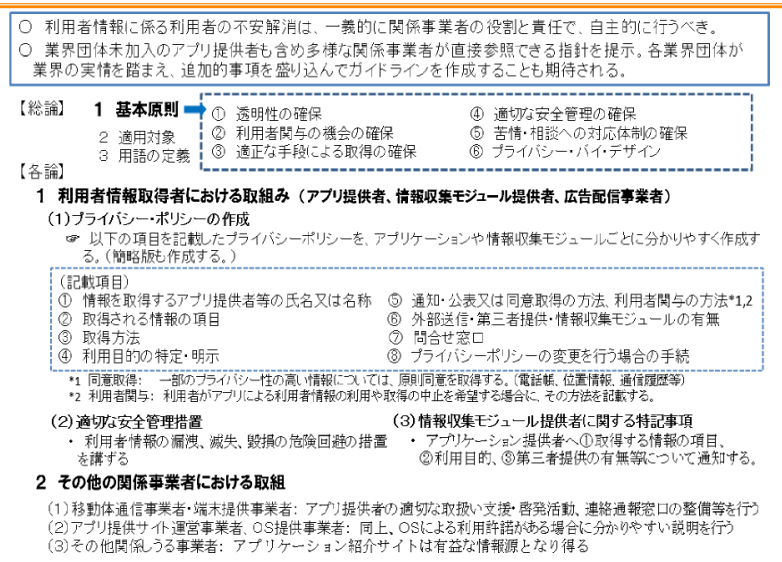

総務省作成資料。総務省「スマートフォン プライバシー イニ シアティブー利用者情報の適正な取扱いとリテラシー向上による 新時代イノベーションー」(http://www.soumu.go.jp/menu_news/ s-news/01kiban08_02000087.html)

図1 スマートフォン利用者情報取扱指針 
して利用される利用者情報にはどのような種類の情 報があるのかを分析した上で，その種類と性質に応 じて具体的にどのような問題が生じる可能性がある のか検討を行っている。

とりわけ，スマートフォンにおける利用者情報の 取扱いには不透明な部分が多いことはすでに述べた とおりである。したがって，実際に取得されている 情報の種類や内容については利用者にとつて認識で きないことが多いことから，本報告書において具体 的にどのような情報が取得され利用されているのか 詳細な分析を行った意義は大きい。

個人情報保護制度についても国内外においてさま ざまな取り組みがなされており，その制度全体につ いて日々新たな対策が検討され実施されていること から大変複雑な状況となっている。そのようなわが 国および諸外国における現状を詳細に分析している ことも，今後のスマートフォンにおける利用者情報 の取扱いにとどまらず，個人情報保護とりわけ新た なサービスにおける個人情報の取扱いに伴う課題お よび対応を分析する上でも，この検討結果を活用す ることが期待される。

個人情報の取扱いについても，個人情報保護法の 解釈を踏まえ利用者情報の性質および分類に応じた 個人情報の取扱いにあたって遵守しなければならな

表4 スマートフォンにおける利用者情報の取扱いに関する課題

\begin{tabular}{|c|}
\hline (1)スマートフォンにおける利用者情報の適正な取扱 \\
\hline (1)スマートフォンにおける利用者情報の性質 · 分類 \\
\hline 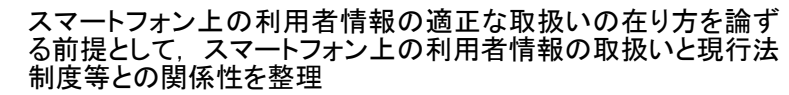 \\
\hline (2)スマートフォンにおける利用者情報の適正な取扱いの在り方 \\
\hline $\begin{array}{l}\text { (1)の整理を踏まえ, 関係事業者等が利用者情報を適正に取り } \\
\text { 扱う望ましい整理 }\end{array}$ \\
\hline (2)利用者に対する情報提供・周知等の在り方 \\
\hline 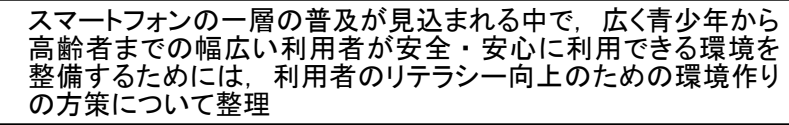 \\
\hline (3) 国際的な連携の推進 \\
\hline 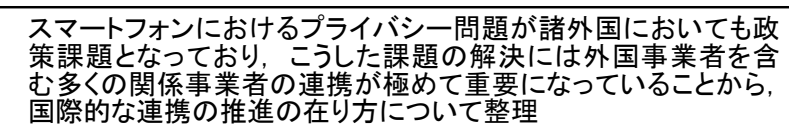 \\
\hline
\end{tabular}

い義務が分析されている。スマートフォンにおける 利用者情報の取扱いについて，個人情報の取扱いと いう観点からは個人情報取扱事業者が遵守すべき義 務と基本的には異なる対応が必要ではないとの前提 に基づき，「スマートフォン利用者情報取扱指針」の 内容は，本来，個人情報取扱事業者が遵守すべき事 項を確認する内容となっている。

\section{8. おわりに}

スマートフォンは，サービスの構造も仕組みも従 来の携帯電話（フィーチャーフォン） とは異なるが ゆえに，不正アプリによる個人情報の不正取得等の 新たな問題が生じていることから，利用者・事業者 双方とも，スマートフォンの特性に応じた対応・対 策が求められている。

しかし，スマートフォンを利用することで非常に 詳細な情報が利用者から取得され，取得される情報 も契約者の個人情報から通信履歴，位置情報に至る まで多岐にわたる。利用者にとっては利用できるア プリの選択肢の幅が広いことから便利さを実感する 一方で，OSの選択肢は限られているため利用者が選 択できるプラットフォームは限られており，アプリ によってどのような情報が取得され利用されている のかを把握·認識できる機会も少ない。つまり, スマー トフォン利用者に関する情報の取扱いの観点からは 事業者側の選択肢が広く，どのような情報を取得し 利用するのかは事業者の裁量に委ねられている一方 で，利用者側の選択肢や利用者が知りうる情報は限 られているのが現状である。ところが，数多くのア プリから利用者が自分の好みに合わせて必要なアプ リをダウンロードし利用者の希望する利用環境を実 現できるがゆえに，利用者情報の取扱いに関し利用 者が限られた範囲でしか関与できないことを，多く の利用者が認識することなくスマートフォンの利便 性に浸っている状況があるといえよう。

そのような不均衡な情報の取扱いが，結果的に利 
用者に不利な状況を招いている。これは，スマート フォンに限らずネットワーク関連のさまざまなサー ビスに共通している問題ではあるものの，スマート フォンを介して取得される情報の多くが，利用者の 日常生活と密接に関わる情報であるためその影響は 大きい。換言すれば，情報の非対称性が極めて顕著 に現れているのがスマートフォンにおける利用者と サービスを提供する事業者との関係といえる。

スマートフォンや携帯端末をはじめとする電気機 器製品の国際市場におけるわが国の地位低下は憂慮 せざるを得ない状況となっている。ネットワークに 関連するサービスに対する法執行の状況についても， 国境を越えた情報流通がネットワークにおいては 日々当然のように行われている現状において，諸外 国には設置されている個人情報やプライバシーの問 題を統一的に国内法を執行し国際的な越境協力執行 に対応するプライバシーコミッショナーのような機 関がないことは，ハード面における地位低下同様に，
国際的な法執行の共助においても地位低下を招いて いることを認識する必要がある。

日本国内において提供されている各種さまざまな 有力なサービスの多くが国外の事業者によって提供 され，国際的にもそのような事業者等が主導権を握つ ている現状においては，国際的に通用する基準に基 づき，諸外国の法執行機関とも協力し適切な法執行 を行うことが不可欠である。

「スマートフォン・プライバシー・イニシアティブ」 は，スマートフォンを対象とした利用者情報の取扱 いに関する指針として，諸外国における対応状況と 比較しても先駆的な取り組みであると評価できる。 スマートフォンを経由した利用者情報の適正な取扱 いを確保するための国内における対応が，諸外国に おける取り組みに先駆けて進んでいる現状において， 今後は，この分野の問題の取り組みにおいて国際的 にイニシアティブをとることができるかが問われて いるといえよう。

\section{本文の注}

注1）スマートフォンの国内普及率は, 9.5\%から18.0\%に増加したとの調査結果がある。日経BPコンサルティ ング.“携帯電話・スマートフォン“個人利用”実態調査2012-スマートフォンの国内普及率は18.0\%， 1 年でほぼ倍増”. 2012-07-25. http://consult.nikkeibp.co.jp/consult/news/2012/0726sp/, (accessed 201210-22).

注2）岡村久道編.クラウド・コンピューティングの法律. 民事法研究会. 2012を参照されたい。

\section{参考文献}

1）山本惇一.急速に普及するスマート端末が世界を変える.インフォコム. 2012, vol. 4, p. 3-8.

2）武田邦宣. ネットワーク中立性に関する新しいFCC規則. Nextcom. 2012, vol. 9, p. 4-11.

3）“不正なAndroidアプリや標的型攻撃の多発ぶりが目立つ2012年第1四半期”. ITmedia. http://www.itmedia. co.jp/enterprise/articles/1204/18/news063.html, (accessed 2012-04-12).

\section{Author Abstract}

The number of smartphone users is drastically increasing. At the same time, users are assailed with anxiety 
by using smartphones. While users are unable to recognise what kind of information is being collected and used through their use of smartphones, non-transparent information-handling is being conducted. The unlawful collection of stored, personal information by companies, individuals and entities which is recorded automatically inside a smartphone, is now leading to the unauthorised, third-party transmission of personal data and this is a result of the deliberate misuse of mal-ware applications. Accordingly, this paper introduces the official, overall guide and the contained guidelines, with solutions to the above-mentioned problems with reference to the current Personal Information Protection Law, from the point of view of both sides of the most recent security and privacy issue research and its link to safe and secure smartphone usage.

\section{Key words}

personal information, privacy, data protection, smartphone, security, 